\title{
LAND USE CHANGES (RECORDED IN OLD MAPS) AND DELIMITATION OF THE MOST STABLE AREAS FROM THE PERSPECTIVE OF LAND USE IN THE KAŠPERSKÉ HORY REGION
}

\author{
RENATA EREMIÁŠOVÁ, HANA SKOKANOVÁ
}

The Silva Tarouca Research Institute for Landscape and Ornamental Gardening, Pub. Res. Inst. (VÚKOZ, v.v.i.), Lidická 25/27, CZ-60200 Brno, Czech Republic, Department of Landscape Ecology, Email: renata.eremiasova@vukoz.cz, hana.skokanova@vukoz.cz

Received: $22^{\text {nd }}$ April 2008, Accepted: $10^{\text {th }}$ April 2009

\begin{abstract}
The paper deals with the development of cultural landscape in the area of study in the Kašperské Hory region, Czech Republic, from the 1730s to the present and documents changes in spatial structure of land use in this period. The aim of the paper is to briefly characterize main phases in land use development and to identify land use changes and their trajectories. The research tries not only to identify spatial changes of land use but also to compare these changes with natural conditions and socio-economic factors. The results show a clear tendency in natural succession, typical for marginal landscapes in the whole of Europe, and to some extent homogenisation of the landscape in the second half of the $20^{\text {th }}$ century. The major trajectories of change concern changes between arable land and permanent grassland. About $20 \%$ of the area remains stable from the perspective of land use which is different in comparison to other similar areas in the Czech Republic. Main socio-economic driving factors that influence land use development are population dynamics, changes in agricultural practises and management policies, whereas natural conditions do not play such a significant role.
\end{abstract}

\section{INTRODUCTION}

Land use is a specific sign of human activities in time and space that includes certain historical, economic, social and cultural potential and that represents an intersection between the natural conditions of the area, technical possibilities and knowledge (Žigrai 1974 in Žigrai 1995). Changes in society, should they be political, economic, demographic or technological, changes in ownership relationships, production methods or technical innovations, are reflected in the use of land (Lipský, Kvapil 2000). Methodological principles of detection and ecological assessment of land use development in terms of historical analysis result from a number of studies (e.g. Lipský 1992, Lipský and Nováková 2004, Haase et al. 2007, Pan et al. 1999, Poudevigne et al. 1997, Rao and Pant 2001, Hietel et al. 2004, Palang et al. 1998, Swetnam 2007).

Analysis of landscape changes, or rather changes in the means of its use, is important especially from the perspective of assessment of both natural and socio-economic 
processes, their dynamics, and causes of stability of current state but mainly from the perspective of possible future development (Feranec 1997). Land use is influenced by two interacting groups of factors. The first group is the natural potential of the landscape (primary landscape structure), which is influenced by human activities, the second one represents means of using the landscape by people (secondary landscape structure).

Landscape structure and the anthropogenic interference with it are mainly researched by analysis of the land use structure. Fundamental sources for the research are represented by old topographical maps that show conditions of "lost" and extinct landscape, provide important information about its development and thus unfold its historical pattern. On the basis of analysis of old topographical maps it is possible to document historical development of land use and create therefore a framework for a more detailed survey of specific landmarks (e.g. Agnoletti 2007, Hamre et al. 2007, Bender et al. 2005). By comparing several maps and plans, both old and current, we can find out how the landscape has been changing over decades and centuries as well as how the spatial texture and configuration of a cultural landscape influences anthropogenic ecosystems and their dynamics (Bender et al. 2005).

Monitoring land use development is a part of the long-term research project MSM 6293359101 - Research into sources and indicators of biodiversity in the cultural landscape in the context of its fragmentation dynamics. The project deals, among others, with the changes of land use in the period 1836-2006. It is based on the analysis of old and modern (mainly military) topographic maps in large to medium scale and aerial photographs with the help of GIS and remote sensing (Eremiášová et al. 2007).

One of the goals of the research project is to assess the land use changes in pre-defined periods and to create digital maps of land use with the emphasis on delimitation of stable and unstable areas and elements of the landscape. The aim of this article is to assess development of the cultural landscape in the study area of the Kašperské Hory region (SW Bohemia, Czech Republic) from the 1730s to the present, to analyse changes of spatial land use structure and to assess the influence of natural and socio-economical driving forces over these changes.

\section{MATERIALS AND METHODS}

Old topographical maps used for the assessment of the land use changes in the Kašperské Hory region are following: maps from the $1^{\text {st }}$ Austrian military survey (1763-1783), maps from $2^{\text {nd }}$ Austrian military survey (1843), both in the scale of 1:28 800, maps from the $3^{\text {rd }}$ Austrian military survey (1878) and their revised forms (1937) in the scale of 1:25 000, the Czechoslovak military topographical maps from the 1950s and 1990s in the scale of 1:25 000 and the Czech topographical base maps (2002-2005) in the scale 1:10 000. Aerial photographs of the area of study (from around 2000) together with the Czech topographical base maps from the 1990s in the scale of 1:10 000 were used as an additional source.

The maps, with the exception of the Czech topographical base maps, were transformed into a digital form by their scanning with the resolution of 300 DPI. Digital maps were, with the exception of the maps from the $1^{\text {st }}$ Austrian military survey, rectified in the SJTSK geo-reference system and subsequently manually vectorized using the on-screen method. The mean positional error ranged from 8 to $20 \mathrm{~m}$. The maps from the $1^{\text {st }}$ Austrian military survey were not rectified due to the absence of a trigonometric network. As a consequence, their vectorization and the subsequent creation of land use maps were not 
possible. Therefore these maps were used only for a rough estimation of spatial land use distribution during this period.

Vectorization of the maps in GIS environment (software ArcGIS) represented the first step in spatial-temporal analyses. Reconstructions of land use maps from the given periods, which are comparable with one another, were created. On the basis of a comparison among map legends of the above mentioned maps, nine land use categories were distinguished (methodology of VÚKOZ, v.v.i., unpublished). These include: 1 - arable land, 2 permanent grassland, 3 - orchard, 4 - vineyard and hop-field, 5 - forest, 6 - water area, 7 built-up area, 8 - recreational area and 0 - other. Land use categories present in the area of study, include arable land, permanent grassland, orchard, forest, water area and recreational area. Vectorized areas in the area of study were partly generalized with the size of the smallest area of approx. $260 \mathrm{~m}^{2}$.

Subsequent land use changes analysis consisted of overlaying vectorized maps and calculating the number of changes between land use categories during the researched period, i.e. turnover according to Swetnam (2007). Comparing maps of six periods, the number of changes ranged from 0 (no change) to 5 (maximum change; see Fig. 3). We can also distinguish similarity (information about the dominance of a category at a particular location throughout the period) and diversity (the number of different categories recorded for the time steps). Turnover, similarity and diversity describe six groups of trajectories of change (according to Swetnam 2007, modified): stable, which records exactly the same land use category in each of the time steps; stepped change, which indicates those locations where one point of change occurred between two land use categories, with stable land use either side of that point of change; cyclical change, which is identified in the areas where change occurred between just two categories; dynamic change with high turnover between many different categories; change with no clear trend, which includes areas experiencing some turnover between different classes but not as frequently as the dynamic areas; and finally quasi-stable change, which reflects the dominant trend whilst still distinguishing localities from those localities that were consistently one category.

Changes were studied between individual time steps; trajectories of change were studied for the whole period of research. Changes and trajectories of change were identified and the most common trends were revealed.

Landscape diversity was investigated on the basis of land use patches, especially their number, average area and average perimeter. On the basis of these data, two diversity indices were calculated, namely the Shannon index $(\mathrm{H})$ and the Patton shape index (SI). The equation for Shannon index is following (Krebs 1989, modified acc. to Palang et al. 1998):

$$
H=-\sum\left(n_{i} / N\right) \ln \left(n_{i} / N\right) \text {; }
$$

where $n_{i}$ - number of patches of type i, N - total number of patches. The Shannon index expresses the rate of heterogeneity and diversity of landscape structures (Guth \&Kučera 1997).

The Patton shape index is defined as $S I=P /(200 \sqrt{\pi A})$ where $P$ is the perimeter (in m) of the patch and $A$ the patch area (in ha) (Patton 1975 in Honnay et al. 1998). The SI describes the deviation of each fragment from circularity (a perfectly circular fragment will have a SI value of 1.0 whereas all other shapes have other values) (Subrat et al. 2000).

To assess the influence of natural conditions over land use, we related land use categories to the available data of relief, mainly elevation, slope and aspect. All data were derived from a digital elevation model. Absolute elevation above sea level was considered. Slope 
was divided into six categories that were modified from categories defined for estimated pedologic-ecological units (Maděra \& Zimová 2004): 0-3ㅇ, 3-7 $, 7-12^{\circ}, 12-17^{\circ}, 17-25^{\circ}$ and $25^{\circ}>$. For the aspect data we used modified classification from Hietel et al. (2004) and thus divided the data into four categories: north $\left(0-67^{\circ}\right.$ and $\left.338-359^{\circ}\right)$, south $\left(158-247^{\circ}\right)$, sunny slopes $\left(113-157^{\circ}\right.$ and $\left.248-292^{\circ}\right)$ and shaded slopes $\left(68-112^{\circ}\right.$ and $\left.293-337^{\circ}\right)$.

\section{DELIMITATION OF THE STUDY AREA - NATURAL CONDITIONS}

The area of study in the Kašperské Hory region extends over 2000 ha. It is situated in the SW Bohemia, more exactly in the southern part of the Plzeňský kraj /the Plzeň region/, $10 \mathrm{~km}$ south of the town of Sušice (Fig. 1). The area is located between the Losenice and the Otava rivers, the Zlatý potok /the Golden Creek/ and the Opolenecký potok /the Opolecký Creek/. The historically important town of Kašperské Hory can be found in the central part, in the elevation of $739 \mathrm{~m}$. The study area represents a region with a unique well-preserved environment, which is supported by the fact that parts of several large-scale protected areas can be found here. The majority of the region is a part of the NATURA 2000 site. The National Park Šumava, which was founded in 1991, extends from the southwest and transforms into the Landscape Protected Area Šumava (established in 1963). The Nature Park Kašperská vrchovina can be found in the vicinity of Kašperské Hory. The characteristic landscape structure with preserved landscape character, where municipalities and their architecture are of importance, is protected.

\section{Fig. 1: Location and delimitation of the area of study}

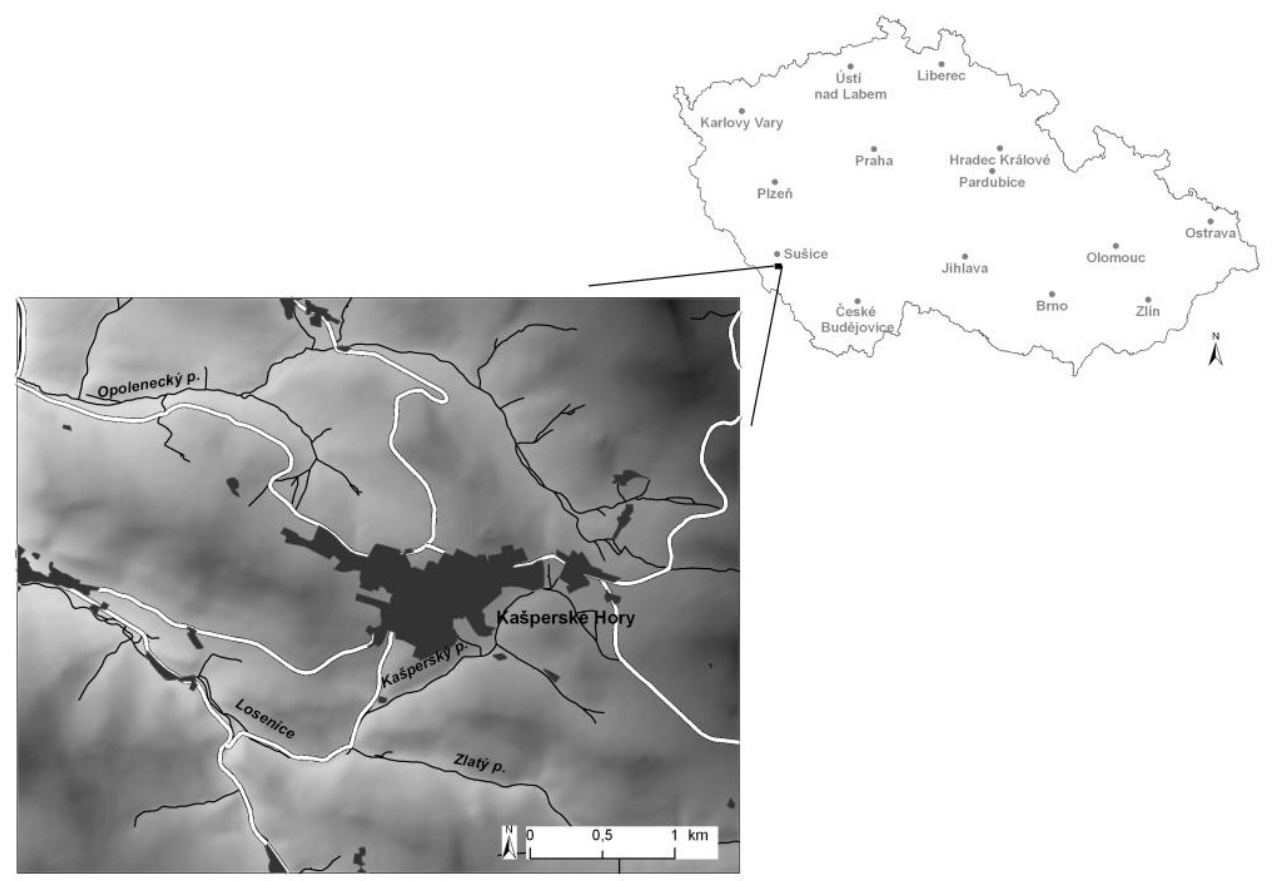

Elevations of the Kašperské Hory region range from $541 \mathrm{~m}$ a.s.l. in the valley of the Otava River to $962 \mathrm{~m}$ a.s.l. on the Chlum Mountain. The western boundary of the study area forms a deep valley of the Otava River, while the southeast is distinctively shaped by 
the valleys of the Losenice River and the Zlatý potok /the Golden Creek/. The relief is created by relatively rugged highland with numerous rock formations. This is reflected in the fact that majority of the area has slope of $7-12^{\circ}\left(36 \%\right.$ of the total area) and $12-17^{\circ}(23 \%$ of the total area). In terms of regional-geomorphological division, the area belongs to the Sumava geomorphological system and is situated between the Šumava Mountains and the Šumavské podhưř́ /the Šumava Piedmont/. The Svatoborská vrchovina/the Svatoborská Highland/ extends here from the north and the Šumavské pláně /the Šumava Plains/ from the south (Demek 1987); they influence the aspect: one third of the study area has the north aspect and one third the south one. The soils are acid and not very fertile. Cambic podzols, dystric and acid cambisols predominate. The majority of agricultural land belongs to the socalled mountain production type. The river network is a part of the Otava River catchment. As for the potential vegetation (Neuhäuslová 2001), herb-rich beech forests with Dentaria enneaphyllos predominate. According to the regional climatic division (Quitt 1970), the area belongs to the cold climatic area of $\mathrm{CH} 7$ (mildly cold and cold mountainous region).

\section{CULTURAL-HISTORICAL DEVELOPMENT OF THE AREA OF STUDY - SOCIO- ECONOMIC ACTIVITIES}

The Kašperské Hory region was selected as an example of the landscape type that was significantly influenced by gold mining and by the transfer of the German-speaking population after WWII. Whereas colonisation and development of the majority of the Czech Republic in the Middle Ages was determined by agriculture, the main driving forces in this region were trade and mining.

After the decline of gold mining in the 1530s, glass making, metallurgy, animal husbandry and logging started to develop in the region. During the $17^{\text {th }}$ and $18^{\text {th }}$ centuries these sectors developed further. An increased demand for timber, which is typical mainly for glass making and metallurgy, significantly influenced the landscape. This resulted in both a decrease in the area of the forest and changes in the forest species composition.

Deforestation reached its peak in the 1830 s, the logging subsequently declined and agriculture became a major source of income. Before that, agriculture had performed only a supplementary role and had been only self-supplying. Natural conditions (climate, geology and soils) were and still are crucial and limiting factors for agriculture in this part of the Czech Republic which is similar to other mountainous areas of the country. Another factor that influenced agriculture was the absence of workforce (Anděra, Zavřel 2003). Some arable land was transformed into permanent grassland as a consequence of intensification of animal husbandry. Traditional and relatively intensive agricultural use of the landscape survived without any major changes until WWII. After the war and with the transfer of the German population some activities were suppressed. Population decrease and political obstructions led to a rapid decrease in pressure on the land, which resulted in gradual natural succession and forest planting on the abandoned arable land. During the 1950s and 1960s independent small land holders and grazing cooperatives were forcibly incorporated into state farms and collective farms. During collectivisation, small fields were consolidated, balks were ploughed, old boundaries and the road network were eliminated. In the process of agriculture intensification, semi-natural, species rich grasslands were transformed to cultural grasslands with high yields. Intensive animal husbandry also became the basis for agricultural production. Concentration and intensification of agricultural production ceased with political changes after 1989. It was possible to gain land again and a new colonisation wave in the form of recreation started taking place 
(Anděra, Zavřel 2003). This trend is supported by the status of the area (part of the National park and the ProtectedLandscape Area of Sumava).

\section{RESULTS}

Development of land use changes in the study area was analysed on the basis of maps from seven time periods since 1764 (maps from the $1^{\text {st }}$ Austrian military survey) till the present. Quantitative analysis was accomplished on the basis of maps from six time periods, with maps from the $2^{\text {nd }}$ Austrian military survey as a starting point.

The use of the maps from the $1^{\text {st }}$ Austrian military survey for quantitative analyses was restricted by the low accuracy and absence of a trigonometric network. Maps were created without geodetic fundamentals and in many cases without any unified rules. These limitations reflected in the fact that the maps from this period were only used for identification of significant historical objects, which have been preserved until today and which are typical for the area of study, and for rough estimation of the spatial distribution of land use. A large proportion of arable land was very distinctive. Permanent grassland was situated mainly in floodplains. In total, the landscape was largely deforested and forests covered a much smaller area than nowadays. This fact was related to the increased demand for timber in glass making and metallurgy. The $1^{\text {st }}$ Austrian military survey corresponds with the period when agricultural intensification only just began and the industrial revolution had not yet occurred (Uhlírová 2002).

The quantitative analysis of digital maps enabled comparison of areas of individual land use categories in the period 1843-2005 (Fig. 2). The most significant changes occurred within the categories that are spatially most widespread, i.e. arable land, forest and permanent grassland. The analysis mainly proved a decrease in the proportion of arable land, the present area of which is at its minimum. A permanent increase in the area of forests was recorded; the area of this category has doubled since 1843. The proportion of permanent grassland registered a slight decrease during the inter war period; it increased again after WWII and today reaches the same proportion as in 1843. The increase in permanent grassland in the $21^{\text {st }}$ century was partly a result of the national and also the European agricultural policy because the area belongs to the category of so-called "less favourite" areas and can thus receive subsidies for grassing the land. The increase in the built-up area was caused by the gradual development of Kašperské Hory. The increase in the recreational area has occurred since the 1990s. Other land use categories form only a small proportion.

To record general landscape changes during the research period, the analysis of these changes was carried out (see Fig. 3). This analysis consisted of overlaying vectorized maps and calculating the turnover (the number of changes in the land use categories in the researched period with the maximum of the changes being five), similarity and diversity. By gradually overlaying maps from the six periods, areas, where no change in land use during the whole researched time period was recorded, were delimitated (see Fig. 4). Area and proportion of the number of changes related to the total area is shown in Tab. 1.

Table 1: Area [ha] and proportion of number of changes in the land use categories 


\begin{tabular}{|c|c|c|}
\hline number of changes & area [ha] & proportion [\%] \\
\hline 0 & 406.3 & 20 \\
\hline 1 & 777.5 & 39 \\
\hline 2 & 423.2 & 21 \\
\hline 3 & 294.4 & 15 \\
\hline 4 & 85.3 & 4 \\
\hline 5 & 13.1 & 0.7 \\
\hline
\end{tabular}

As can be seen in Tab. 2, $20 \%$ of the study area can be marked as relatively stable, i.e. they resisted driving forces causing land use changes. The following $39 \%$ of the total area showed only one change/turnover. If we consider only the turnover and not other indices, we can say that almost $60 \%$ of the Kašperské Hory region is spatially relatively stable from the perspective of land use. The biggest proportion of stable areas is represented by forests (78\%) and permanent grassland $(16 \%)$; the proportion of other categories is notably lower (Tab. 2, Fig. 4). The built-up area of Kašperské Hory can also be assessed as spatially stable. Stable areas of forest occur on slopes with north aspect and inclination of $7-17^{\circ}$, while stable areas of permanent grassland can be found on slopes with south aspect and inclination of $3-12^{\circ}$.

Fig. 2: Proportion of the land use categories within the area of study in the period of 1843-2005

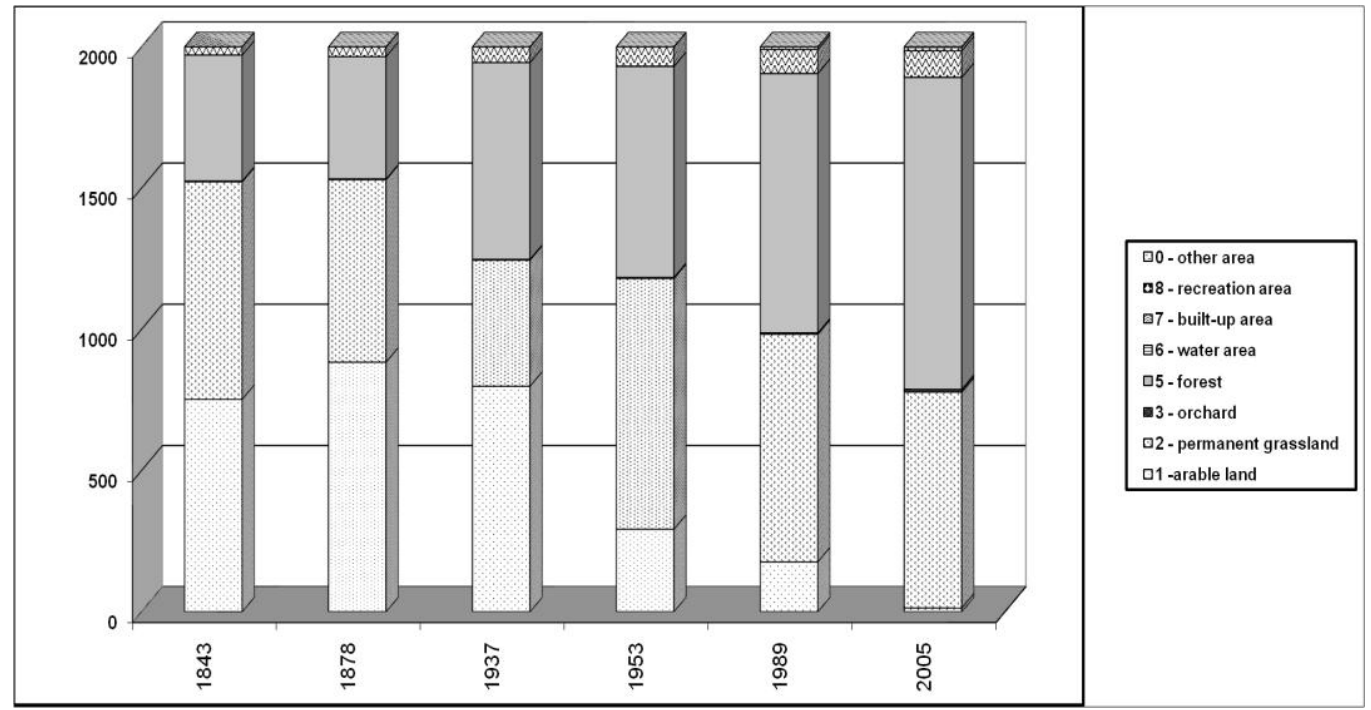

Fig. 3: Number of changes in the landuse categories within the area of study in the period of 1843-2005 


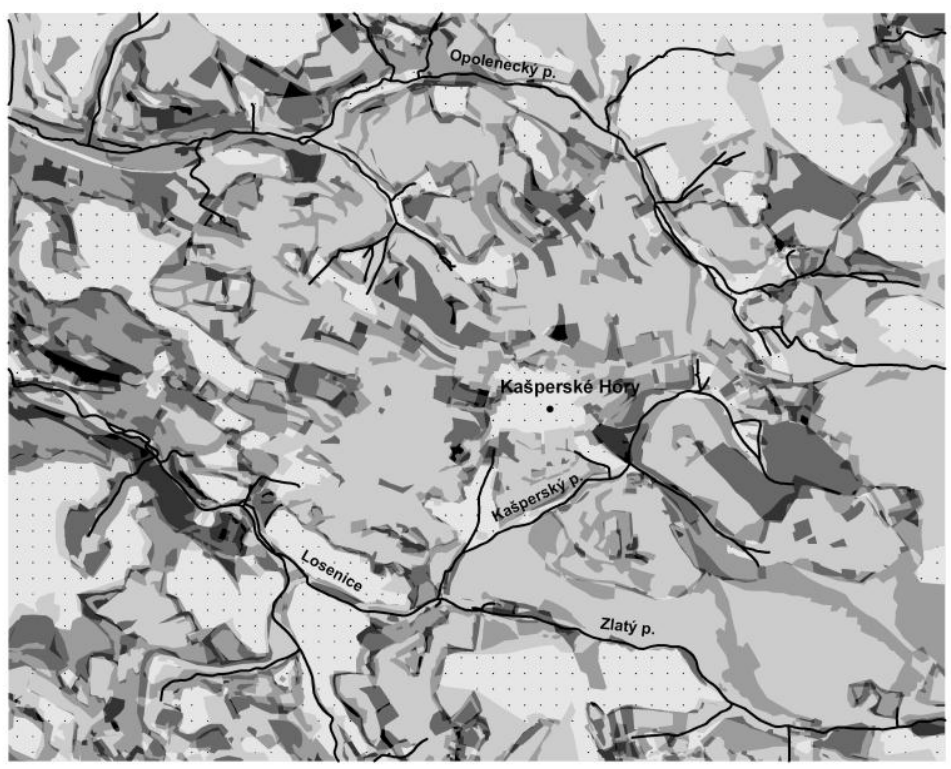

Number of changes

in the land use categories

in the period 1843-2005
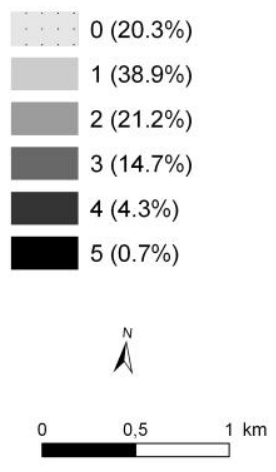

Fig. 4: Stable areas of the land use categories within the area of study in the period of 1843-2005

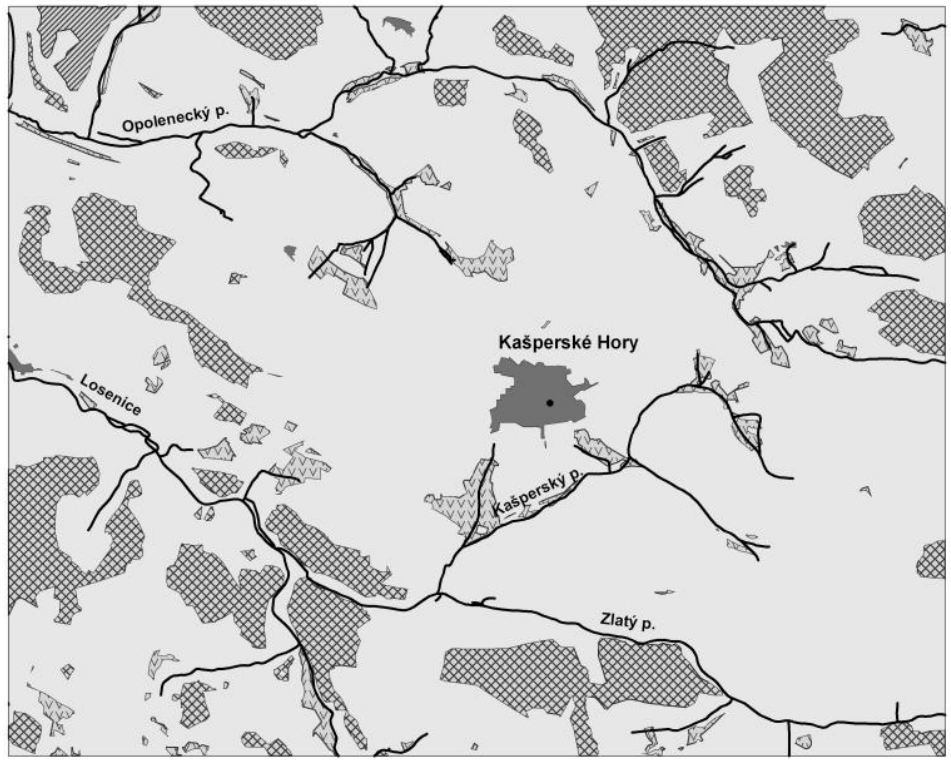

Stable areas of land use categories in the period $1843-2005$

forest

VIIIIIS arable land

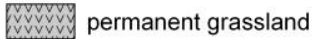

built-up area

changed areas

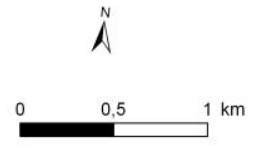

Hana Skokanová, vúkOZ, v.vi.i., 2009

Table 2: Proportion of stable areas according to land use categories 


\begin{tabular}{|l|c|c|}
\hline land use category & area [ha] & proportion [\%] \\
\hline forest & 315.5 & 78 \\
\hline permanent grassland & 10.5 & 3 \\
\hline built-up area & 64.4 & 16 \\
\hline arable land & 16.0 & 4 \\
\hline total & 406.4 & 100 \\
\hline
\end{tabular}

Changes that occurred in the Kašperské Hory region were mainly on arable land, permanent grassland and forest. We identified four groups of trajectories of change out of six described by Swetnam (2007) that were most common in the area of study: stable (19\% of the total area), quasi-stable (8\%), stepped (24\%) and with no clear trend (NCT) (5\%). Stable areas are situated mainly in the northeast and south along the Zlatý potok, while the biggest concentration of quasi-stable areas can be found in the north along the Opolenecký potok and also in the east (see Fig. 5). The majority of the change is expressed as stepped change and is concentrated in a band running from northwest to southeast. Finally NCT areas are dispersed throughout the area of study, with bigger plots north of the Losenice River in the west, east of Kašperské Hory and northeast of the Opolenecký potok in the east. This trajectory of change is associated only with changes between arable land and permanent grassland. Stepped change occurred either between arable land and permanent grassland - this type dominated; or permanent grassland and forest.

Fig. 5: Most common trajectories of change in the area of study in the period of 18432005

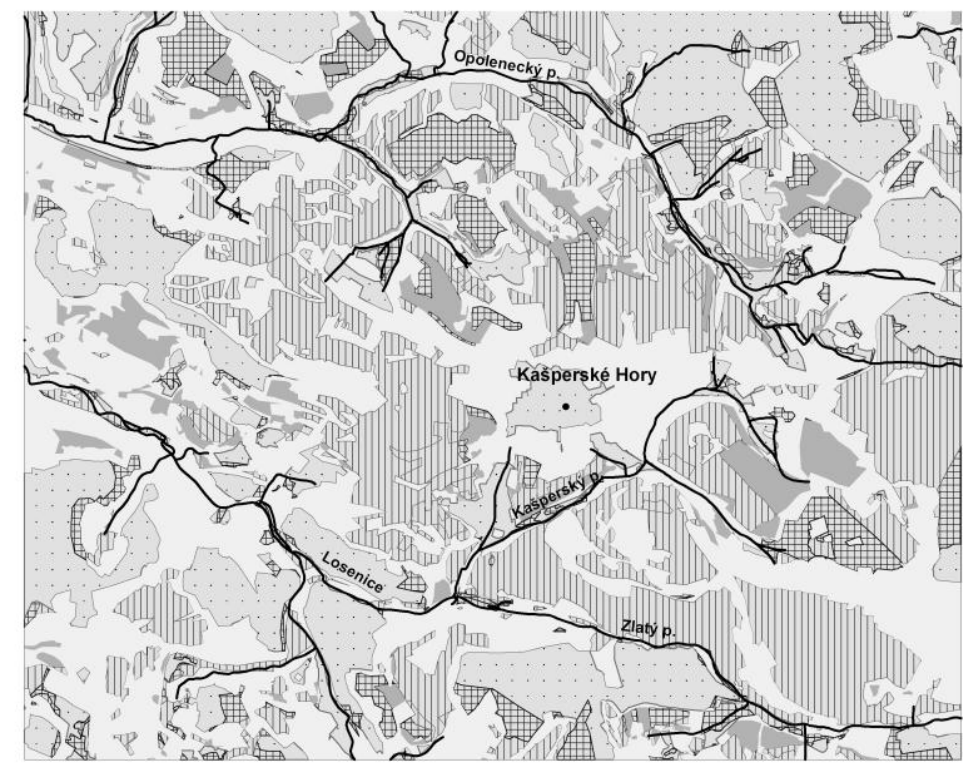

Trajectories of change
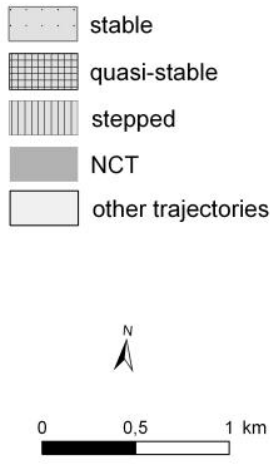

Hana Skokanová, vứKOZ, v.vi.., 2009

Landscape diversity characteristics represented by number of patches, their average area and perimeter as well as the Shannon index and the Patton shape index for each category in the research period are shown in Tab. 3. Number of patches oscillated during the research 
period. The smallest number was recorded for the 1843 time-step, while the biggest number was recorded for the time-step of 1876. The oscillation of the number of patches reflected political and economical changes in the area. The fragmentation at the end of the $19^{\text {th }}$ century reflected increased pressure on land due to the increase in population, which peaked during this period. Decrease in the number of the patches in 1937 was probably caused by the first land reform that was initiated in 1919 and showed the first land consolidation. Another land consolidation, which was a part of the agricultural transformation into socialist system and was of a larger extent, occurred between 1960s and 1970s and meant another decrease in the number of patches. On the other hand, an increase in the number of patches in 1953 can be ascribed to the transfer of Czech Germans and thus to the abandonment of the land. Increase in the number of patches in 2005 was also due to the abandonment of the land but the driving forces were different - disestablishment of state farms, competition in agricultural goods on open market and different management policy exercised by the authorities from the national park and landscape protected area (preference in grassing, recreation). Fluctuation of average area corresponds more or less with the fluctuation of number of patches, i.e. bigger number of patches means smaller area.

The diversity expressed by Shannon index was highest in 1843 and 1937; there was a steep decrease at the end of $19^{\text {th }}$ century and in the 1950 s. Since the 1950 s the decrease was gradual and the landscape became more uniform. Patches were most irregular in 1843 and in 1989. The simplest shape of the patches was characterised for 1937 and 2005.

Relationship between individual land use categories and natural conditions was assessed on the basis of average absolute elevation, slope and aspect. While built-up area, permanent grassland and forests remained more or less in the same average elevation, arable land shows a rapid decrease especially in 2005. If we consider the relationship between land use and slope, we can say that the majority of land use categories occur on slopes with inclination between $3-17^{\circ}$; only built-up area is bound to slopes between $0-7^{\circ}$. There were shifts in the relation to the slope recorded for two categories during the research period arable land and permanent grassland. Arable land was bound to slopes 3-12 ${ }^{\circ}$ in 1843 and then since the 1950s onwards, while between 1878 and 1937 a shift towards steeper slopes occured. This was probably caused by the already mentioned intensification in agriculture at the end of the $19^{\text {th }}$ century and beginning of the $20^{\text {th }}$ century. A shift towards steeper slopes in 1989 noted for permanent grassland reflected collectivisation in agriculture from the 1960s and 1970s. Northern aspect was typical for arable land and forests in 1843 and 1878 and for permanent grassland since 1937 onwards. Southern aspect prevailed during the research period within the category of built-up area. Forests were mostly found on slopes with southern aspect since 1937 onwards, while permanent grassland was situated mainly on that way oriented slopes during the $19^{\text {th }}$ century. Concerning arable land, the majority of the area with southern aspect occurred between 1937 and 1989; in 2005 there was a shift towards sunny slopes. 
Table 3: Landscape diversity characteristics for the land use categories in the researched period

\begin{tabular}{|c|c|c|c|c|c|c|c|c|c|c|c|c|c|c|c|}
\hline \multirow[b]{2}{*}{ category } & \multicolumn{5}{|c|}{1953} & \multicolumn{5}{|c|}{1989} & \multicolumn{5}{|c|}{2005} \\
\hline & No & $\begin{array}{c}\text { aver. } \\
\text { area } \\
\text { [ha] }\end{array}$ & $\begin{array}{c}\text { aver. } \\
\text { perimeter } \\
{[\mathrm{m}]}\end{array}$ & $\mathrm{H}$ & SI & No & $\begin{array}{l}\text { aver. } \\
\text { area } \\
\text { [ha] }\end{array}$ & $\begin{array}{c}\text { aver. } \\
\text { perimeter } \\
{[\mathrm{m}]}\end{array}$ & $\mathrm{H}$ & SI & No & $\begin{array}{l}\text { aver. } \\
\text { area } \\
\text { [ha] }\end{array}$ & $\begin{array}{c}\text { aver. } \\
\text { perimeter } \\
{[\mathrm{m}]}\end{array}$ & $\mathrm{H}$ & SI \\
\hline arable land & 45 & 6,5 & 1436,4 & 0,4 & 1,6 & 22 & 8,0 & 1341,8 & 0,3 & 1,3 & 3 & 4,5 & 642,4 & 0,1 & 0,9 \\
\hline $\begin{array}{l}\text { permanent } \\
\text { grassland }\end{array}$ & 29 & 30,6 & 3900,3 & 0,4 & 2,0 & 32 & 25,2 & 3200,3 & 0,4 & 1,8 & 60 & 12,7 & 2349,8 & 0,3 & 1,9 \\
\hline orchard & 3 & 1,4 & 477,7 & 0,1 & 1,2 & 1 & 5,2 & 1727,9 & 0,0 & 2,1 & 11 & 0,9 & 432,1 & 0,2 & 1,3 \\
\hline forest & 40 & 18,7 & 1899,0 & 0,4 & 1,2 & 28 & 32,8 & 3152,3 & 0,4 & 1,6 & 42 & 26,3 & 3181,2 & 0,4 & 1,8 \\
\hline water area & 5 & 0,2 & 162,4 & 0,2 & 1,1 & 7 & 0,1 & 131,9 & 0,2 & 1,1 & 9 & 0,1 & 127,4 & 0,2 & 1,1 \\
\hline $\begin{array}{l}\text { built-up } \\
\text { area }\end{array}$ & 20 & 3,4 & 841,5 & 0,3 & 1,3 & 16 & 5,3 & 1006,3 & 0,3 & 1,2 & 24 & 3,9 & 844,0 & 0,3 & 1,2 \\
\hline $\begin{array}{c}\text { recreational } \\
\text { area }\end{array}$ & & & & & & 4 & 2,3 & 701,1 & 0,1 & 1,3 & 5 & 2,5 & 730,9 & 0,2 & 1,3 \\
\hline other area & 1 & 0,2 & 153,6 & 0,0 & 1,1 & & & & & & 2 & 0,8 & 411,2 & 0,1 & 1,3 \\
\hline average & 20 & 8,7 & 1267,3 & 0,2 & 1,3 & 16 & 11,3 & 1608,8 & 0,2 & 1,5 & 20 & 6,5 & 1089,9 & 0,2 & 1,3 \\
\hline
\end{tabular}




\section{DISCUSSION}

Digital processing of old maps provides information about the spatial distribution of individual land use categories and about comparison of changes in their proportion in the given period. However, it is necessary to be cautious about drawing strong inferences when analysing fine-scale patterns because of the potential errors inherent in the interpretation and overlay of land use maps (Pan et al. 1999). Two types of error can be identified there - the attribute classification one and the positional one (Chrisman 1989 in Pan et al. 1999). Interpretation of the older maps, mainly those from the $2^{\text {nd }}$ Austrian military survey, is rather problematic and can cause the attribute classification error due to the fact that the relief in these maps is represented by the so-called "Lehman hatches" and thus more difficult to read. Positional errors may be caused by the rectification of the maps and their scanning and influence mainly analyses based on the basis of overlaying individual vectorized maps. We tried to keep both types of errors to a minimum - in the first case we checked vectorized maps several times; in the second case we eliminated small patches that had specific characteristics (narrow, elongated shape, very small, almost zero area). We found that removing these small patches had no significant effect on the results of land use changes and other landscape indices, which corresponds also with the findings of Pan et al. (1999).

The land use development in the area of study reflects general trends of mountainous and/or marginal areas not only in the Czech Republic but in Europe as a whole (see e.g. Agnoletti 2007, Olsson et al. 2000, Hamre et al. 2007, Demek et al. 2007, Riezner 2007). Abandonment of farming activities and the sharp decrease in the resident population has clearly favoured natural ecological succession (Agnoletti 2007). Dramatic population drop occurred after the Second World War, which corresponds with the population development of the mountainous region of Tuscany, Italy (Agnoletti 2007); however, this drop was caused by the transfer of the Czech Germans and not by industrialization. An increase and development of tourism has been recorded since the 1960s (which is recorded on the 1990s map), which is similar to the processes in mountainous valleys in Norway (Olsson et al. 2000).

Assessment of land use changes can be processed both between individual time-steps and for the whole period of research. Trajectories of change should be calculated for the whole research period in order to have predicative values. They are based on calculation of three indices - diversity, similarity and turnover. The turnover captures the most interesting information about the process of change and is therefore perhaps the most valuable index while constructing the stability map (Swetnam 2007). However, it is very important to consider all three indices together otherwise the results can be misleading. Stable areas express a typical example: if we consider areas with turnover 0 and 1 only as spatially relatively stable, they cover $60 \%$ of the total area, which corresponds with areas in the Czech Republic that have to some extent similar conditions (e.g. border hilly area, mining hilly area), as the national park Podyjí (Skokanová \& Havlíček 2008), Rosice-Oslavany region (Skokanová and Stránská 2008) or the Javorník region (Demek et al. 2007). But if we consider all three indices then the stable and quasi-stable areas cover only up to $30 \%$ of the total area which is different from the above mentioned studies.

There are four groups of trajectories of change that dominate in the study area: stable, stepped, and quasi-stable and with no clear trend. Similar results were recorded for ten sample sites in England and Wales out of 23 (Swetnam 2007). Also changes recorded for two study areas in a German marginal rural landscape can be ascribed to the first two groups (see Hietel et al. 2004). Unlike in the study by Swetnam (2007), the most common 
trajectory of change there was from arable land to permanent grassland with the turnover occurring in around 1953. This might be caused by different natural conditions of the areas, their management or simply by the generalization of the results from 23 sample sites.

There is no clear trend in the regime of number of patches and their average area, unlike in other studies throughout Europe that record gradual reduction in number and an increase in average size of the patches (e.g. Hamre et al. 2007, Agnoletti 2007, Haase et al. 2007). We can strongly associate the fluctuation of these characteristics with the socio-economic driving forces, especially changes in agricultural practices, population development and management policies. These findings correspond with those of Bičík \& Chromý (2006): "Changes in landscape structure on a local level reflect mainly the influence of external political and economical conditions and basic changes connected with population development and transition from mainly self-supplying system to an open one - with free movement of goods on the national or even on the international level". If we consider results for the Shannon index, we can agree with the findings of Olsson et al. (2000) that the former patch dynamics resulting from the large diversity in former land use, is about to disappear, and a more homogenous landscape can be expected.

Results for the relationship between land use categories and natural conditions indicate that natural conditions play some role in the distribution of land use categories but they are not the dominant driving factor.

\section{CONCLUSIONS}

As the results of this article indicate, land use categories in the Kašperské Hory region are to some extent influenced by natural (physical-geographical) conditions of the environment but mainly by socio-economic needs and demands of society. Major changes in the area of study occurred after WWII through the transfer of the German population and changes in agricultural practices. Nowadays the landscape is influenced mainly by the open market economy, agricultural policy on both national and European level and management policy exercised by the national park and protected landscape area authorities.

The results confirm general trends in natural succession in marginal landscapes throughout Europe and also certain uniformity of the landscape since the 1950s. On the other hand, we found no clear trend in the regime of number of patches and their average area.

We can say that it is important for the ecological stability of the landscape to delimitate eco-stabilizing components, areas and structures of cultural landscapes. It is possible to historically delimitate the most stable areas from the perspective of land use by using the method presented in this article. However, only field surveys of the state of the actual vegetation will determine their real ecological value.

\section{ACKNOWLEDGMENTS}

This research was supported by research project MSM 6293359101 Research into sources and indicators of biodiversity in cultural landscape in the context of its fragmentation dynamics. 


\section{REFERENCES}

Agnoletti, M. (2007). The degradation of traditional landscape in a mountain area of Tuscany during the 19th and 20th centuries: Implications for biodiversity and sustainable management, Forest Ecology and Management, 249 (1-2), p. 5-17.

Anděra, M., Zavřel, P. (2003). Šumava (přiroda, historie, život). Baset, 800 pp.

Bender, O., Boehmer, H. J., Jens, D., \& Schumacher, K. (2005). Analysis of land-use change in a sector of Upper Franconia (Bavaria, Germany) since 1850 using land register records, Landscape Ecology, 20 (2), p. 149-163.

Bičík, I., Chromý, P. (2006). Změny ve využití země ve vybraných modelových územích Česka, In Šimůnek, R. (Ed.), Historická geografie, pp. 189-204. Supplementum I., Historický ústav, Praha,

Demek, J. (1987). Hory a nižiny - zeměpisný lexikon ČSR. Academia, Praha, 584 pp.

Demek, J., Havlíček, M., Mackovčin, P. \& Slavík, P. (2007). Landscape changes in the Czech Republic 1763-2005: An assessment based on historical maps and GIS technology, Nova Acta Leopoldina, 94 (349), p. 187-200

Eremiášová, R., Havlíček, M. \& Mackovčin, P. (2007). Quantitative analysis of landscape development and mapping of drainage network based on historical maps: case study of the surroundings of Kašperské Hory town (Czech Republic). Silva Gabreta, 13 (3), p. 285-300

Feranec, J. (1997). Analýza zmien krajiny aplikáciou údajov diaĺkového prieskumu zeme. Geographia Slovaca 13. Geografický ústav SAV, Bratislava, 64 pp.

Guth, J., Kučera, T. (1997): Monitorování změn krajinného pokryvu s využitím DPZ a GIS. Príroda, 10, p. 107-124

Hamre, L. N., Domaas, S. T., Austad, I., \& Rydgren, K. (2007). Land-cover and structural changes in a western Norwegian cultural landscape since 1865, based on an old cadastral map and field survey. Landscape Ecology, 22 (10): 1563-1574.

Haase, D., Walz, U., Neubert, M., \& Rosenberg, M. (2007). Changes to Central European landscapes - Analysing historical maps to approach current environmental issues, examples form Saxony, Central Germany. Land Use Policy, 24 (1): 248-263.

Hietel, E., Waldhardt, R., \& Otte, A. (2004). Analysing land-cover changes in relation to environmental variables in Hesse, Germany. Landscape Ecology, 19 (5): 473-489.

Honnay, O., Hermy, M. \& Coppin, P. (1999). Effects of area, age and diversity of forest patches in Belgium on plant species richness, and implications for conservation and reforestation. Biological conservation, 87 (1): 73-84

Krebs, C. (1989). Ecological Methodology. HarperCollins, New York, 654 pp.

Lipský, Z., Kvapil, D. (2000). Současné změny ve využívání (Nové funkce venkovské krajiny?). Životné prostredie, 34 (3): 148-153

Lipský, Z. (1994). Změna struktury české venkovské krajiny. Sborník České geografické společnosti, 99 (4): 348-260.

Lipský, Z., Nováková, E. (1994). Historický vývoj krajiny a mapování biotopů. In Anonymus (Ed.), Mapování biotopů. p. 89 - 93. Sborník semináře k 75. výročí VŠZ Brno

Maděra, P., Zimová, E. (2004). Metodické postupy projektováni lokálního ÚSES, Ústav lesnické botaniky, dendrologie a typologie LDF MZLU v Brně, Löw a spol., Brno - CDROM 
Neuhäuslová, Z. (2001). Mapa potenciální přirozené vegetace ČR. Academia, Praha, $341 \mathrm{pp}$.

Palang, H., Mander, U., \& Luud, A. (1998). Landscape diversity changes in Estonia, Landscape and Urban Planning, 41 (3-4): 163-169.

Pan, D., Domon, G., de Blois, S., \& Bouchard, A. (1999). Temporal (1958-1993) and spatial patterns of land use changes in Haut-Saint-Laurent (Quebec, Canada) and their relation to landscape physical attributes . Landscape Ecology, 14 (1): 35-52.

Poudevigne, I., van Rooij, S., Moring, P., \& Alard, D. (1997). Dynamics of rural landscapes and their main driving factors: A case study in the Seine Valley, Normandy, France. Landscape and Urban Planning, 38 (1-2): 93-103.

Quitt, E. (1970). Mapa klimatických oblastí ČSSR. Geografický ústav, ČSAV, Brno Patton, D.R. (1975). A diversity index for quantifying habitat edge. Wildlife Society Bulletin, 3: 171-173

Rao, K. S., Pant, R. (2001). Land use dynamics and landscape change pattern in a typical micro watershed in the mid elevation zone of central Himalaya, India. Agriculture, Ecosystem and Environment, 86 (2): 113-123.

Riezner, J. (2007). Vývoj využití půdy v horním povodí Opavice v letech 1845-2003. Klaudyán 4 (2): 28-41

Skokanová, H., Havlíček, M. (2008). Vývoj krajiny národního parku Podyjí. In Popková, K., Šmída, J. (Eds.). Sborník abstraktů. 164 p. Geodny Liberec.

Skokanová, H., Stránská, T. (2008). Land use changes as a reflection of environmental and socio-economic factors. In: Vaishar, A., Zapletalová, J. (Eds.): Eurorural '08 Investigating European Countryside. Abstracts of papers of the $1^{\text {st }}$ Moravian Conference on Rural Research EURORURAL '08, p. 105-106. Brno, Czech Republic, August 25-29.

Sharma, S., Palni, L.M.S. \& Roy, P.S., (2009, February). Analysis of Fragmentation and Anthropogenic Disturbances in the Himalayan Forests: Use of Remote Sensing and GIS. GISdevelopment.net Forest. 2000.

Swetnam, R. D. (2007). Rural land use in England and Wales between 1930 and 1998: Mapping trajectories of change with high resolution spatio-temporal dataset. Landscape and Urban Planning, 81 (1-2): 91-103.

Uhliŕrová, L. (2002). Současný stav využití starých map pro sledování krajinných změn. In Němec, J. (Ed.), Sborník z konference „,Krajina 2002 od poznání k integraci“, Ústí nad Labem, MŽP, Praha

Žigrai, F. (1974). Využitie pol'noshospodárskej krajiny vo vzt’ahu k jej ekologickým vlastnostiam v SZ časti Liptovskej kotliny. Acta Univ. Palackianea Olomoucensis. Fac. Rer. Nat., Biologia, 47 (15): 343 - 346

Žigrai, F. (1995). Integračný význam studia využitia země v geografii a krajinném ekológii na príklade modelového územia Lúčky v Liptove. In Drgoňa, V. (Ed.), Geografické štúdie, (IV), 129 pp. Nitra 